\title{
MANAGER OF TODAY AND OF THE FUTURE: E-MANAGER
}

\author{
Jasmina Starc ${ }^{1}$
}

DOI: https://doi.org/10.31410/LIMEN.2019.7

\begin{abstract}
The goal of this article is to consider which skills a manager has/will need and will use if he wants to achieve above-average results. Today, the manager must be focused on himself, be responsible for his own knowledge and development, and at the same time take full responsibility for the advancement and development of all employees. A good manager hears what others do not hear, sees what others do not see, and feels what others do not feel. The most successful manager is the one who has an open mind, is sincere, change-oriented, curious and creative. He is a master of soft skills that are based on relationships with everyone he interacts with and he masters the relationships with society. Today, in a time of constant change in technology, he must also have a well-developed computer literacy, since modern management of an organization is not possible without a highly developed computer information system.
\end{abstract}

Keywords: Modern e-manager, Modern manager skills, Computer literacy.

\section{INTRODUCTION}

$\mathrm{D}^{\prime}$ rucker (1992, in: Kanjuo Mrčela, 1996, p. 14) states that rarely has any institution in human history appeared so suddenly and had such a rapid and great effect as management. He defines management as a „new social function” that has completely transformed the social and economic fabric of this world in less than 150 years. Management emerged when large business organizations began to emerge - organizations (late 19th century) - in which they had to coordinate the work of a large number of people performing various tasks. The only such large organizations at this time were war organizations; they were a model and role model for large organizations. From these, the concepts of control and command of a small group of people have taken over the large crowd within the strictly hierarchical structure of the organization.

Over time, management acquired new forms, functions and dimensions. Management has always monitored and responded to changes in organizations. It also promoted change and development in organizations, so it's no coincidence that theories of organization and management seemed close and even overlapped. Management represents the most important function in the organization (Fayol, 1949; in Bahtijarević-Šiber et al., 1999, p. 445).

Management has evolved - like many other scientific disciplines - into practice. Although some of the scientific bases of management date back to the nineteenth century, the systematic development of modern management as a scientific discipline began in the early twentieth century and coincides with the development of industry. Since then, many professional publications have been published in the world of management, and the manager has become one of the highest paid professions. 


\section{MANAGER OF TODAY AND OF THE FUTURE: E-MANAGER}

Research has shown that it takes 15-20 years to develop a top manager. The main factors that make it successful are: $10 \%$ represents education, $20 \%$ success depends on the people with whom it works, and $70 \%$ represent experience (part-time studies, early leadership experiences, creating something from scratch, restructuring, project work, increased responsibility, problems, etc.).

The manager of the future is responsible for his knowledge: he will decide on resources, create his own ideas about phenomena, use his time for his own experience, connect data with new circumstances, etc. (Krajnc, 1996, p. 9). The focus is on interdisciplinary education, which requires the manager to have comprehensive knowledge, skills, new habits and a combination of information from different disciplines.

Schein (2004, p. 287) outlines the characteristics that the manager of the future is expected to possess: an extraordinary ability to perceive and insight into himself and the real world; exceptional motivation ability that will enable him to overcome the difficulties that arise in the learning phase through change; emotional strength that will help overcome fears of learning and change that will become part of everyday life; the willingness and ability to involve others in the organization, because the tasks will be too complex and the information will be too much for the manager to handle; the will and ability to share power and control according to the knowledge and skills of the participants, which means allowing and promoting leadership throughout the organization.

In addition to the qualities already mentioned, the future manager will be a person who will be able (Hesselbein et al., 1996, p. 154): to lead and to follow; sometimes being the center, sometimes the fringe of what is happening; be sometimes up, sometimes down on a hierarchical scale; to work alone and in a team and be an eternal student.

The new profile of the manager, established in the beginning of the $21^{\text {st }}$ century, must be convincing, and above all, he must be able to motivate his colleagues and attract them with personal example. One major challenge for the management of the future will be to match and complement the goals of the organization and the personal goals of the employees (including management). As early, Görg (1991, p. 12) announced the following changes in management in the future:

- The trend of internationalization of the economy, while increasing national and regional independence;

- The company evolves into an entertainment company. At the same time, the social impact of productivity is growing;

- The public is becoming increasingly critical of the industry. At the same time, he is becoming increasingly aware of the crucial role of the economy in achieving socio-political goals and solving socio-political problems;

- Public morale levels are rising and private morale is falling.

According to Mayer (2002), the modern manager has the following characteristics:

- Intelligence in terms of responding quickly and appropriately to change. Very intelligent people, as a rule, are not good leaders, because they are more focused on dialogue with themselves than with others, thoughts overtake the words spoken, so expression is less comprehensible. However, leaders are above average intelligent. Their intelligence is also reflected in the performance of several rules (so-called parallel processing); 
- Personality in the narrowest sense, among which the following qualities stand out among managers. Dominance (or dominance), which is an internal tendency to power over others. The next feature is extraversion (openness), which opens up possibilities for communication, exposing one another's interactions, emotional expressiveness. Emotional stability or neutral emotional state5. Honesty is one of the qualities of a manager that contributes to the employees' confidence that the tasks are fairly distributed and objectively evaluated. However, honesty usually relies only on one's own conduct. Therefore, the honesty of a manager must be closely linked to responsibility for others. As a last personality trait, there is a reliability that relates to and is committed to fulfilling promises and agreements;

- Creativity as the next trait of managers and understood as a human ability to outgrow what has already been created. Creativity cannot be planned, but encouraged and expected. Creative managers are those who have no tongue hair, deal with things thoroughly and are stubbornly persistent. They also think in their own way. They are enriched with a rich imagination and are original and humorous in their actions. The creative mission, then, is the art of promoting the creative work of colleagues. If a leader is able to instill the joy of working and socializing and inspiring colleagues for top achievements, creativity comes automatically;

- Expressiveness as a trait of managers is welcomed in the process of entrusting tasks, in various presentations, in business negotiations, in mentoring and in public appearances. It is a complex messaging ability and skill. Expressiveness is teachable. Its lightness, comprehensibility, interestingness and persuasiveness of expression of the manager directly influence all those to whom the message is intended;

- Empathy (the ability to experience another) is, in contrast to expressiveness, a natural reality that cannot be learned. It provides a deeper insight into yourself, which is especially important for personal maturation - as a key item in shaping self-image. It is especially important when the positions of the manager and associate are diametrical (that is: completely opposite);

- Positive self-image is the ticket to the circle of leading personalities. The person who trusts, is satisfied with himself, is self-critical and progress-oriented can successfully lead others. Negative attitude towards oneself excludes affection for others - the basis for cooperation;

- Determination (or courage) are also qualities of a good manager. Although the belief is that no man can be decisive in all situations, in all cases. In practice, however, it turns out that determination is dependent and expressive on the emotional component of givenness;

- Altruism and philanthropy are the basic attitudes of the manager towards his colleagues. A good leader is always in the background and exposed only when needed. In doing so, he does not neglect caring for others in arousing a sense of importance and need;

- Ethical principles are the core of conduct that directs the person from the value and the differential - the biological to the valence of the human. The sense of good/bad, just/ unjust develops in the process of education, which means that ethics is learnable and that its key source is interpersonal relationships. The most important goal of ethical development is a good man, who is also the primary trait of a good leader.

Given the complexity of the tasks (and expected personality traits) that the manager of the future will have to perform, we believe that he will need a wide range of skills that will allow him flexibility, dynamism, adaptation to new changes, risk taking and increasing responsibilities, etc. Therefore, it is very important for the future of continuing education and training for managers, both formal and informal, that it will constantly ensure that programs are relevant to the needs of businesses. State and private educational institutions will have to develop, update 
their programs (teaching content), supplement their teaching forms, methods and resources. Only in this way will they attract (educate) managers, otherwise they will remain outside the management development flow and without demand for their ,products”. Given the economic and political integration of European countries, they will have to liaise with foreign educational institutions and involve (recognized) foreign lecturers with international experience.

Managers are becoming increasingly aware that, in addition to being responsible for their own knowledge and development, they must also take full responsibility for the advancement and development of employees and all employees. Because they will have to cope with all the global challenges that will always require new skills, they will need to be educated on a permanent basis. Krajnc (2002, p. 221) emphasizes the importance of developing one's own identification of an individual, which enables him / her to open communication, integration at a higher democratic level in relation to other people. A manager with a formed identity will be able to accept and tolerate the otherness and diversity of others, as he must actively confront the processes of globalization aimed at accepting the world as one community.

\section{A MODERN E-MANAGER}

The shift from e-commerce to business is a change across the organization, not just a replacement for new technologies. The Internet economy is changing everything: the way organizations are managed, the organizational culture, and managers are required to acquire new skills. The Internet requires many new skills, but it is believed that a good manager can also become a good e-manager. Certain quality attributes of managers have become even more important in the modern economy than they have been before (Penger, 2001, p. 25).

The past few years have seen a remarkable development of information literacy around the world. Data, information and knowledge are crucial for each individual. Nowadays, information literacy is no longer relevant only to individuals, but to the whole economy and all the population. We know many forms of information literacy, and they are all very important. It is important both in e-learning and in other traditional forms. Information literacy is very important today for most workers and jobs (Grčar et al., 2006, pp. 1-2). Information can take many forms: textual, graphic, audio visual. They are available to us in various places, in the mass media, on the Internet, in the library, within the local community, in interest organizations. This information is made available to users in unfiltered form and doubts about its authenticity, reliability and validity are raised. Since a wealth of information does not make itself an informed individual; an individual needs a whole range of interrelated skills to use the information effectively. We need to create an information literate (Miller, 2016, p. 6).

Information literacy is generally defined as the ability to identify information needs, to obtain, evaluate and use information from a variety of sources. It is a widespread concept of traditional literacy because it binds to the use of any character system and involves the understanding and creative use of information also transmitted through modern computer, communication and reproduction technology. It is development oriented. It is an integral content of human continuous learning, learning to master it so that we can learn, explore (Novljan, 2002, p. 10). Javrh et al. (2018, p. 13) describe the concept of digital literacy as a fundamental ability of an individual to use and function in the digital world. Digital literacy is the ability to safely and critically use information society technologies in a variety of fields: at work, in leisure, and to communicate with others. A key component of this capability is digital competence. Digital literacy encompasses 
the critical and secure use of digital technology at work, for personal leisure and communication. Fundamental computer knowledge, such as the use of a computer to search, evaluate, store, produce, present and share information, and to communicate and participate in shared networks on the Internet, is fundamental. For example, digital literacy in everyday life means that an individual is able to install a proper tablet game on their child, share beautiful travel clips with their friends, have no problems online shopping, making online payments, etc. A digitally literate individual knows and uses digital appliances and gadgets, such as computers, smartphones, and web tools, and can connect and update them for his or her personal needs, while being skilled enough to use this knowledge and he does his job easily. Using digital technology, it searches for and manages a variety of information, communicates and performs various tasks in many ways. It manages various mobile and computer applications. He knows how to choose the right path to reach his goal, and understands the legalities of the digital social environment and finds itself in it.

An information literate person should know at least the lowest level of the computer (basic computer equipment, media, input and output units), should be able to operate, start and shut down the computer, use input and output units, adjust the desktop, edit the computer settings, use the Internet (basic on security, web browser, bookmarks, searching information on the internet, printing) and working with email (spam, electronic communication) (Borse, 2006, pp. 3 - 4). An information literate person is capable to (Stopar, 2010, p. 7):

- identify and identify the information need,

- obtain the necessary information effectively and efficiently,

- critically evaluate information and information resources,

- integrate selected information into your background knowledge,

- successfully use the information to achieve a more specific goal,

- understand the economic, legal and social aspects of the use of information and obtain and use information in accordance with ethical rules and regulations.

Lavtar (2003, pp. 14-19) summarizes the seven dimensions of literacy:

- Tool literacy: the ability to understand and use practical and conceptual information technology tools (software, hardware) relevant to the education, field of work and personal life of the individual. Basic computer and network application programs are included;

- Literacy for the use of resources: the ability to understand the forms, formats, locations of information resources and methods of accessing them, especially the development of network information resources. This definition most closely matches the concepts of information literacy by librarians and contains the concepts of classification and organization of information resources;

- Socio-structural literacy: means knowing how and how information is socially shaped. This means how it suits the various groups in society. It also means knowing the institutions (universities, libraries, companies) that create and organize information, knowledge;

- Research literacy: encompasses the ability to understand and use the tools of today's researchers (e.g. computer programs for quantitative and qualitative analysis);

- Publishing literacy: the ability to design and publish research and ideas electronically, in text and multimedia formats (including WWW, CD-ROM, e-mail);

- Technology literacy: the ability to adapt, understand, evaluate and apply information technology innovations;

- Critical literacy: the ability to critical evaluate the intellectual, human and social strengths and weaknesses, capabilities and limitations, benefits of information technology. It includes a historical, socio-political and cultural perspective. 
The most important skills and abilities of the modern e-manager are presented in the table below.

Table 1: The most important features and capabilities of an e-manager

\begin{tabular}{|c|c|}
\hline The ability & Identifying the content to which the ability relates \\
\hline Speed & $\begin{array}{l}\text { Speed of business depends not only on the Internet and support technologies, but on } \\
\text { the ability of the e-manager to make quick decisions. In the Internet age, management } \\
\text { performs activities in parallel rather than sequentially. }\end{array}$ \\
\hline $\begin{array}{l}\text { Ability to learn and } \\
\text { develop }\end{array}$ & $\begin{array}{l}\text { Human capital is the most important resource of modern organization. Talented } \\
\text { and capable employees must be allowed personal development. In recent years, the } \\
\text { Internet has created jobs such as information architect, e-commerce manager and } \\
\text { knowledge manager. }\end{array}$ \\
\hline Openness & $\begin{array}{l}\text { An OECD survey found that business openness is emerging as a strategy. } \\
\text { E-businesses disclose information to business partners through access to databases. } \\
\text { This requires mutual trust. }\end{array}$ \\
\hline $\begin{array}{l}\text { Ability (virtual } \\
\text { collaboration) }\end{array}$ & $\begin{array}{l}\text { An e-manager must be able to work with the team, employees and outsiders, who are } \\
\text { increasingly remote, so he must learn new ways of virtual collaboration. Because of } \\
\text { the Internet, teams are physically and temporally separated. }\end{array}$ \\
\hline Standards & $\begin{array}{l}\text { In the age of e-commerce, when software replaces people's work, management must } \\
\text { clearly define e-commerce standards. }\end{array}$ \\
\hline Good communication & $\begin{array}{l}\text { E-managers must have the ability to communicate effectively across business } \\
\text { units within the organization and with external members. The horizontal network } \\
\text { architecture enables direct communication of the employee with the senior manager } \\
\text { and removes the intermediate links. }\end{array}$ \\
\hline Content management & $\begin{array}{l}\text { E-managers must ensure that the Internet image is successful, provides proper } \\
\text { navigation and contains the right content. More complex pages mean harder updates } \\
\text { with new features and higher maintenance costs. }\end{array}$ \\
\hline Customer focus & E-managers need to focus on increasingly individualized customer relationships. \\
\hline $\begin{array}{l}\text { Knowledge } \\
\text { management }\end{array}$ & $\begin{array}{l}\text { E-managers need to develop a philosophy of knowledge management. The } \\
\text { development of complex databases and intranets enables companies to acquire, retain } \\
\text { and impart knowledge. }\end{array}$ \\
\hline $\begin{array}{l}\text { Keeping employees } \\
\text { through cases }\end{array}$ & $\begin{array}{l}\text { Management must first and foremost encourage the use of Internet technology by all } \\
\text { employees. }\end{array}$ \\
\hline Internet literacy & $\begin{array}{l}\text { The Internet age manager must be literate in order to take advantage of the immediate } \\
\text { availability of information and data over the network. }\end{array}$ \\
\hline $\begin{array}{l}\text { Strategic decision } \\
\text { making }\end{array}$ & $\begin{array}{l}\text { Because of the speed dynamics, e-managers must be able to make quick decisions } \\
\text { about strategic, non-routine content. }\end{array}$ \\
\hline
\end{tabular}

Source: Penger, 2001

Information literacy enables managers to be more responsible in jobs and careers. Information literacy enhances their competences in evaluating, managing and using information (Stopar, 2010, p. 9).

\section{CONCLUSION}

The importance of digital technology in both the personal lives and work environments, and therefore the digital skills needed to make the best use of it, have been constantly growing in the past decades.

Managers must have developed the following digital skills: instrumental skills, structural or informational skills, and strategic skills, which refer to the ability to use the information proactively to affect one's professional and personal environment.

According to Fau and Moreau (2018, p. 24) managers should focus on three areas to create and enabling environment: Digitization of businesses, by providing a framework and incentives for 
businesses to adopt new technologies and update their working practices by integrating digital technologies. This creates a demand for digital skills that can foster and enhance the development of such skills internally and externally (workplace training courses, specialized courses in higher education, etc.); technological infrastructure, through investments aimed at providing quality high-speed Internet access, reducing access costs, connecting populations in remote regions; the development of online content (locally relevant content, content in local languages, etc.) to create a virtuous circle in which enhanced content is both a driver and a consequence of digital skills.

\section{REFERENCES}

Bahtijarević-Šiber, F. (1999). Management ljudskih potenciala. Zagreb: Golden marketing. Borse, N. (2006). Računalniška pismenost za odrasle. Novo mesto: RIC.

Dimovski, V. in sod. (2005). Učeča se organizacija. Ustvarite podjetje znanja. Ljubljana: GV Založba.

Fau, S. and Moreau, Y. (2018). Managing tomorrow's digital skills: what conclusions can we draw from international comparative indicators? United Nations Educational, Scientific and Cultural Organization, Education Sector. https://unesdoc.unesco.org/ark:/48223/pf0000261853 (Accessed on 18 December 2019)

Görg, B. (1991). Prihodnost menedžerjev, menedžerji prihodnosti. Ljubljana: DZS.

Grčar, A. in sod. (2006). Informacijska pismenost med teorijo in prakso - vloga visokošolskih in specialnih knjižnic. Ljubljana: Abo grafika d.o.o.

Hesselbein, F. in sod. (1996). The Leader of the Future: new visions, strategies and practices for the next era. San Francisco: Jossey-Bass.

Javrh, P. in sod. (2018). Digitalna pismenost. Ljubljana: Andragoški center Slovenije.

Kanjuo Mrčela, A. (1996). Ženske v menedžmentu. Ljubljana: Enotnost.

Krajnc, A. (1996). Kakšno znanje potrebuje sodobni človek. Andragoška spoznanja, 1996, št. 3 , str. $5-10$.

Krajnc, A. (2002). Kdo se lahko vseživljenjsko izobražuje. In: Klapan, A. (ur.); Matijević, M. (ur.): Obrazovanje odraslih i cjeloživotno učenje: zbornik radova međunarodne konferencije Obrazovanje odraslih u Republici Hrvatskoj u kontekstu cjeloživotnog učenja: book of proceedings of the International Conference Adult Education in the Republic of Croatia in the Context of Lifelong Learning. Zagreb: Hrvatsko andragoško društvo, str. 217-224.

Lavtar, D. (2003). Informacijska pismenost. Diplomsko delo. Ljubljana: Univerza v Ljubljani Fakulteta za družbene vede.

Mayer, J. (2002). Ustvarjalna organizacija. 21. znanstvena konferenca o razvoju organizacijskih ved, Portorož, 27.-29. marec, 2002. Management in Evropska Unija: Zbornik posvetovanja z mednarodno udeležbo. Kranj: Moderna organizacija, str. 192-201.

Miler, B. (2016). Informacijska pismenost dijakov po končani osnovni šoli-primer dijakov prvih letnikov srednjih šol na Koroškem. Diplomsko delo. Maribor: Univerza v Mariboru, Fakulteta za naravoslovje in matematiko.

Novljan, S. (2002). Informacijska pismenost. Revija za področje bibliotekarstva in informacijske znanosti, 46, št. 4, str. 7- 24.

Penger, S. (2001). Vpliv nove ekonomije na temeljne funkcije managementa v organizaciji 21. stoletja. Magistrsko delo. Ljubljana: Ekonomska fakulteta, In: Dimovski, V. in sod. (2005). Učeča se organizacija. Ustvarite podjetje znanja. Ljubljana: GV Založba, str. 86.

Schein, Edgar H. (2004). Organizational culture and leadership. San Francisco: Jossey-Bass.

Stopar, K. (2010). Merila in kazalci informacijske pismenosti v visokem šolstvu. Ljubljana: Zveza bibliotekarskih društev Slovenije. 